\title{
Stakes and Limits ff the Installation of a Tool "E-Competences" in SME of the BTP
}

\author{
Franck Brillet, Annabelle Hulin and Martineau \\ University Loire Valley, CERMAT, IAE of Tours, France
}

\begin{abstract}
The interest of this article will be on the one hand to draw up a panorama of the reality of E-HR in France taking into consideration practice and tools but it will be interested, on the other hand with a particular example, that of SME, seldom studied under this aspect. It is also advisable to carry out a choice of tool and the authors privilege one of those on which he is not current to be interested, that of competences.
\end{abstract}

The problems of this study are thus summarized around the following question: which are the stakes and the limits of the placement of a E-HR tool? And more precisely, which are the reasons of the recourse to a E- HR tool dedicated to the management of competences and which are the difficulties and the limits that poses? The study is interested in the installation of a tool, the National Bank of Data of Competences (NBDC) creates by the professional branches of the Public Buildings and Works Sector (PBWS) in SME.

Keywords: tool, competence, appropriation, futurology.

\section{Introduction}

These last years were remembered by a generalization of information technologies and communication (TIC) in companies (Kalika and al, 2003). They seek to answer three major purposes: to inform, communicate and coordinate (Breton, Proulx, 2002). All the sectors, all the trades, all the organizations are concerned with the passion for these technologies. Kalika underlined in 2000 the importance of the passage of management to the E-management, which it defines as "integration in the whole of the processes of management: i.e., finalization, organization, animation, control of the impacts and appropriatenesses of new technologies of information and communication (NTIC)" (p. 68). Thus, as well as the other functions of the organization, the Human Resource Management (HRM) is concerned with the development of the use of the TIC. To characterize these evolutions, we speak about E-RH. In this context, we a a

Copyright (C) 2010 Franck Brillet, Annabelle Hulin and Martineau. This is an open access article distributed under the Creative Commons Attribution License unported 3.0, which permits unrestricted use, distribution, and reproduction in any medium, provided that original work is properly cited. Author contact: Franck BRILLET, e-mail: franck.brillet@univ-tours.fr. 
multiplication amongst tools at disposal them organizations to manage the fundamental activities of the HRM. The HRM calls upon computerized management tools for which "the stress is not laid any more on the administrative one but on tools $R H$ supporting of the specialized activities and the managerial processes (recruitment, formation, evaluation, remuneration)" (Laval, Thierno Diallo, 2007: 124). Many interrogations are posed as for the utility of these management tools and their omnipresence in the organizations. One wonders thus which can be their role in the dynamic organisational ones (Lorino, 2002). Why the organizations resort to it do? Do the search of the performance, the research of the creation of value alone explain the recourse to E- HR? Which are the principal HR policies which are concerned; can one all computerize? Can one speak about choice or acts it of constraints imposed on the organizations? Would the nature of the competing environment or even the current context of the crisis explain a massive recourse to the computerized management tools? In can parallel of these points, one also wonder whether these tools, their introduction and their implementation relate to any type of organization? This is why the interest of this article will be on the one hand to draw up a panorama of the reality of E-HR in France taking into consideration practice and tools but it will be interested, on the other hand with a particular example, that of SME, seldom studied under this aspect. It is also advisable to carry out a choice of tools and the authors privilege one of those on which he is not current to be interested, that of competences. The problems of this study are thus summarized around the following question: which are the stakes and the limits of the placement of a E- HR tool? And more precisely, which are the reasons of the recourse to a E- HR tool dedicated to the management of competences and which are the difficulties and the limits that poses? The study is interested in the installation of a tool, the National Bank of Data of Competences (BNDC) creates by the professional branches of the PBWS, in SME of the sector. After having pointed out the theoretical framework which makes it possible to connect E-RH and management of competences (1), we will present the case of an empirical study led within SME of the sector of the $P B W S$ (2). We will finish by a discussion of the results and a presentation of the various possible prolongations (3).

\section{E- HR and competences: elements of conceptual and theoretical clarification}

The delimitation of the concept of E- HR must enable us to propose the impact of the use of the TIC in the process of management of competences of the organizations.

\subsection{The reality of E- HR in France}

We, initially, will specify what we understand by TIC (1.1.1.), for then clarifying various dimensions of E- HR (1.1.2.). Lastly, we will see how it is possible to resort to the TIC for the management and the evaluation of competences (1.1.3).

\subsubsection{Development of the TIC:} about which realities do speak we?

First of all, it appears important to bring certain elements of conceptual and semantic clarification. The TIC do not correspond to a single reality. Isaac (in Kalika and $\mathrm{Al}, 2003$ ) presents the various types of existing technologies:

- technologies Internet: it is about the most visible shutter and most known of the use of the TIC in the companies. 
"The installation of corporate networks resting on protocol TCP/IP allowed the deployment of Intranets of company, but also of extranets with business partners, who they are suppliers or customers" (Isaac, 2003: 24, in Kalika and Al 2003). Indeed, one attends a strong development of new production and division equipments of information related to the extension of Web 2.0. ;

- technologies related to the information systems: the Eighties and Nineties marked the significant development of Information Systems adapted to Human Resources (ISHR) (Benjamin, 2003). They relate to mainly the operational and administrative tasks of the HRM ;

- technologies of telecommunications: the development of mobile telephony allowed the nomadism of the employees (Kalika, Laval, 2006). Each one becomes reachable almost in real time.

\subsubsection{Various dimensions of $E$ - $\mathrm{HR}$}

The development of E- HR (Kalika and Al, 2005 ) is characterized by many activities; the most known and the most used are:

- E-recruitment: the process of recruitment remains relatively identical but "the speed and manner of returning in relation and of identifying the candidates were modified by rise to power of Internet" (Szelerski, 2009: 66). The arrival of the generation $\mathrm{Y}$ also explains the need for adapting the recruitment of certain organizations confronted either with problems of attractivity or to problems of shortage of competences. Thus E-recruitment can give an image different from the organization and better answer waitings and the practices of this new generation;
- the E-learning: it is "about a process of training by which the individuals acquire new competences or knowledge thanks to information technologies and communication" (Favier and $\mathrm{Al}, 2004$ ). Many are the companies or the training companies which resort to it. Using this tool, the companies seek to adapt the "modes of consumption" of the formation to the employees, but they also seek a tool of training and acquisition of knowledge closer to the employees. It is the latter which will become actor of its formation within a time, nevertheless imposed by its organization. One does not owe also isolated of this tool two often neglected points: the search for a less cost of the formation compared to traditional seminars and technical dimension as well in the design as in the use.

\subsection{Impact of the TIC on the HRM}

Laval and Thierno Diallo (2007) develop the ascribable evolutions with the TIC as regards HRM:

- operational impact: it is the decentralization of certain administrative tasks of the HRM. For example, the TIC facilitate the management and the organization of the formation (Benjamin, 2003);

relational impact: "The groupware makes it possible using tools of the NTIC to make work people on joint projects through a flexible organization in which each one can interact with the other members of the project" (Fayon, 2009: 80);

- impact transformationnel: Laval and Thierno Diallo (2007: 132) consider that the "technological changes have a 
strong organisational impact, in particular on management, socialization, coordination and control".

The TIC are present today in the majority of the processes relating to the HRM. For about ten years, one has observed an important diffusion of computerized tools dedicated to the management of competences, and in particular to their evaluation.

\subsection{The recourse to the TIC for the estimated management of employment and competences}

The diffusion of the TIC within the HRM concerns the instrumentation of the management of competences. Certain computerized tools are developed in order to facilitate the estimated steps around competence and it is there the object of our research.

Before apprehending the estimated models of HRM (1.3.2.), it seems important to us to treat the question of the management tools vis-a-vis E- HR (1.3.1.).

\subsubsection{Management tools and E- HR}

It seems also important to clarify the concept of management tools and to try to apply it to the activities of E- HR.

Authors having proposed definitions from the management tools (Berry, 19985; Hatchuel and Weil, 1992; Moisdon, 1997; Gilbert, 1998; Lorino, 2002; De Vaujany, 2005b) insist on the variety of the forms which they can take: they go from the material object (like a computer), to conceptual tools (an up-dating rate), via tools of decision-making (a model of strategic analysis), devices (like a control system of management) or procedures (Berry, 1985). At all events, the management tools are always average materials or conceptual. The posture adopted by the researchers "refuses to reduce the tool to its technical substrate, formal, but postulates that the tool is a mixed entity associating on a side of the artefacts, materials or symbolic systems (of the concepts, diagrams, interfaces of computer tools...), other of the registers of actions, use which will give them direction". (Grimand, 2006: 17). This design of the management tools borrows from work of Rabardel (1997), which defines the instrument as made up of two elements in interaction: "The instrument is a composite entity which understands a component of artefact (an artefact, a fraction of artefact, or a set of artefacts) and a component design (designs of use, themselves often related to more general designs of action)." (Rabardel, 1997: 39). The component of artefact is a material artefact or symbolic system, produced by the subject or others; the artefact indicates the products of the human activity intentionally made up like material objects or symbolic systems finalized. The component design consists of associated designs of use, resulting from a clean of subject, autonomous construction or of an appropriation of the social designs of use already formed outside with him.

A E- HR software, starting from this definition, could be "read" like the meeting of an artefact symbolic system (the interface of the software) and direction given by the users to this tool, located in a context and a specific culture. It will then be a question of being interested in the social and cognitive influences actors and not only with the technical functionality of the tool.

\subsubsection{Estimated models of Human Resource Management}

There does not exist commonly allowed terminology (Gilbert, Parlier, 2005). We take 
again here the generic term suggested by Mallet (1991: 66): the estimated human resources definite like "the whole of the steps, procedures and methods having for objective to describe and analyze the various possible futures of the company in order to clarify the decisions relating to human resources". Gilbert (1999) releases four historical periods characterized by evolutionary designs of the estimated human resources:

- the estimated management of manpower (years 1960): the models used are limited to a quantitative and calculable aspect. They are of two types: models of simulation (rate of recruitment, rate of turnover...) and the models of optimization (determination of the value of certain parameters which must respect imposed constraints);

- the estimated management of the careers (1970-1975): this orientation was primarily applied to the management of the executives. "It proceeds of an anticipated search for adequacy of the individuals to the uses of the company. Its usual tools are the definition of function, the appreciation of the potential and the flow charts of replacement" (Gilbert, 1999: 68). Management takes a more human face (Cadin and $\mathrm{Al}$, 2007). Following the first oil crisis, the passion for the forecast is blown, the forecasters having been unable to envisage such a crisis (Gilbert, Parlier, 2005);

- the estimated management of employment (years 1980): jointly with the awakening of the need for preventing the economic difficulties, the industrial large companies are the first to initiate a step of estimated management of employment. In 1981, association
"Development and Employment" return clarifies the management of employment. She recommended to position preventive dimension in the center of the approaches of estimated management of employment (Dietrich, Parlier, 2007);

- the estimated management of competences (years 1990): the estimated management of human resources returns towards a qualitative and individualized approach. The objective is to develop the employability of the employees in and out of the company.

The preceding developments attest the importance of the question of the tool of HRM vis-a-vis technologies. In the prolongation of our analysis, the talk and the presentation of the estimated HR models show the need and the reasons which the organizations can have to computerize them. We thus now will present a case of computerized tool dedicated to the management of the competences implemented in SME.

\section{Empirical study: change and difficulties encountered by SME of the PBWS}

This part structure in four points. The first presents the positioning of the study and the methodology implemented (2.1.). The second point presents the company, ground of research, as well as the studied tool (2.2.). The last point is interested in the results of our study (2.3.).

\subsection{Positioning of research and methodology}

Our empirical study proceeded over one 18 months period within the company "J", that is to say between January 2005 to July 2006 . 
The data-gathering was led according to the method of the participating observation. Introduced by Bogdan and Taylor (1975), it makes it possible to the researcher to adopt an internal point of view and to be immersed personally in the daily newspaper and the life of the organization. We adopted a positioning of "participant-observer" (Baumard and $\mathrm{Al}$, 2004). Our objective was to try "to understand the company of the interior while living, at least partly, the "same situations" as the experts" (Hlady Rispal, 2002: 176). The double statute of paid and observer was known of all the members of the organization. The difficulty is that the statute of member of the organization can sometimes prevail on the statute of researcher. Our work within this company concerned the optimization of the process of management and evaluation of competences, and in particular on the use and the appropriation of a E- HR tool: the National Bank of Data of Competences (NBDC) of the $P B W S$, which we will present in the following paragraphs.

Throughout our presence on the ground, we held a log book. This last "consists of hard copies, left by a researcher, whose contents relate to the narration of events (to the very broad direction; the events can relate to ideas, emotions, thoughts, decisions, facts, quotations or extracts of reading, descriptions of things seen or words heard) contextualized (time, the people, places, argumentation) which the goal is to remember the events, to establish a dialog between the data and the researcher at the same time like observer and analyst, to look at oneself like another" (Baribeau, 2005: 108). In the log book of the researcher, several types of notes were established (HladyRispal, 2002; Baribeau, 2005; Coutelle, 2005):
- notes of ground: they are descriptive notes on the various events, the people present, the various actors, the temporal aspect... ;

- methodological notes: they relate to the control of research directly;

- notes of analysis: referent with the impressions and with felt of the researcher.

\subsection{Presentation of the ground}

\subsubsection{The company J}

The company J is SME of 170 paid, created in 1933, based in the Center of France. Its competitors are all the construction companies or of public works which, on the local scales, regional or national intervene on the same type of activity. The sector being extremely concentrated, the company $\mathrm{J}$ is measured with great national groups such as Vinci or Bouygues Construction. In this context of strong competition, the maintenance and the development of the line of business result from the implementation of a marketing policy founded on three principles: the quality of the council to the customers (necessary upstream of the project), the respect of the times and the constraints of execution and the quality of work (policy-holder by the men of the company). The company avoids to the maximum the recourse to temporary work or subcontracting.

The strategic planning of the company $\mathrm{J}$ is built around four axes:

- to ensure the development of the company: to improve the trading position, to improve the economic performance, to anticipate the internal 
and external evolutions and to prepare the transmission of the company;

- to mobilize the personnel: to improve the ascending and downward internal communication, to interest the personnel in the life of the company;

- to make evolve the quality system, management tool to the service of the customer: to make sure of its effectiveness, to develop the spirit of permanent and continuous improvement;

- to develop the safety spirit and to improve the work conditions: to implement safety policy, to acquire new rules of organization of work.

The budget formation accounts for $6 \%$ of the wages. The company also avoids the recourse to temporary work or subcontracting.

\subsubsection{The computerized tool dedicated to the management of competences}

The National Bank of Data of Competences $(N B D C)$ of the PBWS has been worked out by group OPCA-GFC-AREF for 20 years. It describes the whole of the activities, tasks and know-how related to the building sites. It is about a computerized database, personnalisable by the companies users. This tool must enable them to create their own reference frame of employment and to be used as essential tool for the implementation of the estimated management of employment and competences.

Objective books of the days the "competences" of 1998 organized by MEDEF (ex-CNPF) expose the principal characteristics of this computerized management tools: "the NBDC is a whole made up starting from the observations on the ground of the advisers in formation, of the studies carried out on the evolution of the trades of the PBWS, the Reference frames of Occupations of State education... This information was mutualisées, processed and placed at the disposal of the companies in the form of a computerized and updatable tool".

The five objectives laid down initially by the professional branches for the use of the $N B D C$ are: analysis of the line of business and employment, determination of the required qualification levels, the evaluation of competences of the employees, the finalization of the development plan of competences of the employees, facilitation of the human stock management. The NBDC covers 32 corporations today and gathers nearly 300 jobs. To the level of the professional branches, its management belongs from now on to the prospective observatory of the trades and the qualifications of the PBWS. The implementation of the BNDC within the company J began in 2002. A project team made up of the president, of the administrative and financial director, the person in charge of HRM, the logistic person in charge and two clerks of works, was made up. A consultant wich specialized in HRM accompanied this project team for the implementation by the software in the company but also for the constitution of the reference frames of competences and for the management training to the conduit of talks of evaluation. The construction of the reference frame of competences lasted nine months. On the basis of contained information in the $N B D C$, the company J managed to develop a reference frame gathering all necessary competences at the realization of its building sites and according to seven qualification levels: workmen of 
execution (levels 1 and 2), workmen professional (levels 1 and 2), workmen of control (levels 1 and 2) and site foremen. This reference frame also istinguishes six professional behaviors common to all the hierarchical levels: the sense of the customer ${ }^{1}$ objectives of building site, the compliance with the rules, management, autonomy and the initiative, flexibility and the versatility. The employees are positioned according to five levels of criteria of evaluation presented in the following table:

Table 1: criteria of positioning of the employees for the six professional behaviors awaited by the company.

\begin{tabular}{|c|c|}
\hline- & Unacceptable behavior or detected serious error, requires a radical change \\
\hline$-=$ & $\begin{array}{l}\text { Cannot make, competences to be acquired or always does not make, needs to improve its } \\
\text { constancy }\end{array}$ \\
\hline$=$ & Conform to waiting \\
\hline$=+$ & Regular result and above objectives \\
\hline+ & $\begin{array}{l}\text { Is driving with respect to his/her colleagues (collaborator or for the company), force of } \\
\text { proposal }\end{array}$ \\
\hline
\end{tabular}

The technical skills necessary to the realization of the building sites and the professional behaviors compose the cards used for the biannual talks of evaluation, made up starting from the $N B D C$. The latter also makes it possible to integrate the history of the employee, his course, the followed formations and the possible remarks and requests emitted during maintenance (remarks relating to the formation, the remuneration and evolution of the qualification). Thus, the appraiser has all the useful information with the control of maintenance. In addition, the use of software NBDCalso supports the treatment of the evaluations by means of cartographies and diagrams.
The follow-up is allowed thanks to the conservation of hard copies of each maintenance of evaluation carried out. The first session of individual talks of evaluation was led in 2003. The second session proceeded in 2005, it is at the second that we took part. The initial objective was truly to develop the use of this computerized tool. The individual talks are organized every two years. Nevertheless, of the intermediate talks can be installation following a change of qualification or with a new recruiting.

\subsection{Results and come up against limits}

The results of our empirical study attempt to underline the evolutions observed following

\footnotetext{
${ }^{1}$ As illustration, for a foreman, the reference frame specifies that for the professional behavior "compliance with the rules", waitings of the company are the following ones: "it respects and makes respect the rules of procedure, it applies and makes apply the prevention and security instructions. He is Co-person in charge of safety on building site. He sets up and monitors the safety devices relating to the building site. He is concerned safety for the transport of the personnel. Does not have problem with alcohol. Respect the schedules. Respect the material, the tools, the installations of building site. It transmits information to $N+1 "$.
} 
the installation of software $N B D C$ (2.4.1.) and the main difficulties encountered (2.4.2.).

\subsubsection{Evolutions observed following the installation of software NBDC}

As illustration, following session 2003 of the talks of evaluation, the ratio of promotion was of $12.7 \%$ and the wage bill increased by $5.5 \%$. At the time of the session 2005, the ratio of promotion was of $8 \%$. In a general way, the employees are rather petitioning of this kind of talks, of this moment of exchanges with their hierarchically superior. The use of this computerized management tools allows more objectivity and of

transparency in the attribution of the modes of recognition and valorization to the employees. For example, the pay rises allotted to some paid can be justified on the basis of history of individual evaluation of competences present in the NBDCof the company.

The analysis of the reports of the individual talks of evaluation also makes it possible to plan the formations necessary to each employee.

\subsubsection{Limits come up against following the installation of software NBDC}

At the time of session 2005 of the individual talks of evaluation, several difficulties and limits were come up against on the various levels of the company. They are presented and detailed in table 2 below.

\section{Discussions and prolongations}

According to Gilbert (2006), "the most satisfactory results of computerization meet whenever the step of estimated HRM preexists to the introduction of the software". That means that the use of E- HR tool applied to the estimated HRM does not guarantee of anything emergence new practices. The setting use of the tools is not automatic. The case study presented watch the example of computerized management tools which by its implementation and the observations carried out bring two types of reflections in prolongation of our analyzes: the first relates to the crucial question treating of the tool and the appropriation with the actors (3.1.); the second raises the question of the futurology of the trades, problems introduced by the object even of this tool "Ecompetence".

\subsection{Problems of the appropriation of the tools E- HRapplied to the estimated HRM}

According to certain designs, intrinsic qualities of the tools and qualities of their design are enough to define them, to even explain their "success". Indeed, if these qualities are sufficiently relevant in term of profit of effectiveness and efficiency for the organization which receives them, the rational computation of the actors will have quasi-mécaniquement to support his use, according to the principle according to which the "intendance will follow" (Grimand, 2006). But this design concerns the model of instrumental rationality (Hatchuel and Weil, 1992): the agents of the organization are pressed on a set of tools which form in their eyes a suitable representation of the current location and specify the possible ways of improvement taking into account the criteria of performance in question, and these same agents conform to the precepts thus released by the various diagrams of reasoning that they developed. 
Table 2: difficulties encountered following the installation of software

\begin{tabular}{|c|c|c|}
\hline $\begin{array}{l}\text { Function of } \\
\text { the company } \\
\text { concerned }\end{array}$ & Explanations & Extracts of the log book of the researcher \\
\hline $\begin{array}{l}\text { Human } \\
\text { Resource } \\
\text { Management }\end{array}$ & $\begin{array}{l}\text { Software NBDCwas not installed in } \\
\text { network in center of all the offices of the } \\
\text { company. Only, the same HR person } \\
\text { and we could interact on the tool. That } \\
\text { required an additional work for the } \\
\text { RRH. } \\
\text { Software NBDCwas regarded as not very } \\
\text { ergonomic. }\end{array}$ & $\begin{array}{c}\text { "How does one make when it does not have nobody } \\
\text { with RH there?" - "that requires a job not possible to } \\
\text { prepare all that" } \\
\text { "It is not very pleasant to work with the NBDC, it is } \\
\text { not clear" }\end{array}$ \\
\hline Direction & $\begin{array}{l}\text { The management of the firm never used } \\
\text { management tools NBDC. Its use was } \\
\text { entirely delegated to the HR person. } \\
\text { The direction was not organized to } \\
\text { examine the requests and the remarks of } \\
\text { the employees as fast as possible after } \\
\text { the course of each maintenance of } \\
\text { evaluation. }\end{array}$ & $\begin{array}{l}\text { "The president is very taken. It is really difficult to } \\
\text { take time with him to work. The telephone always } \\
\text { sounds or of people strike." } \\
\text { "It is on full with files at the same time, it is not } \\
\text { always easy. He does not delegate enough" }\end{array}$ \\
\hline $\begin{array}{l}\text { Clerks } \\
\text { works }\end{array}$ & $\begin{array}{l}\text { As appraisers, they were not completely } \\
\text { autonomous in the preparation of their } \\
\text { talks. } \\
\text { They had the feeling to know their } \\
\text { employees and not to need a } \\
\text { maintenance formalized to exchange } \\
\text { with them. } \\
\text { Problems of the management of the } \\
\text { difficult personalities (the refusal, the } \\
\text { negative one, the shift enters individual } \\
\text { perception and reality). } \\
\text { The application of the grid of evaluation } \\
\text { related to the six professional behaviors } \\
\text { awaited by the company (direction of } \\
\text { the customer, objectives of building site, } \\
\text { compliance with the rules, management, } \\
\text { autonomy and initiative, flexibility and } \\
\text { versatility) was not easy for the } \\
\text { appraisers. }\end{array}$ & $\begin{array}{l}\text { "I will want to be able to organize me as I want, but } \\
\text { with this software it is not always easy" } \\
\text { "I do not need that to speak with my guy. I think } \\
\text { nevertheless that I am accessible" } \\
\text { "They want nothing to say, they are never agreement, } \\
\text { it is not possible with them" } \\
\text { "They did not understand all the grid of evaluation in } \\
\text { the same way. There are very important variations". }\end{array}$ \\
\hline $\begin{array}{l}\text { Workmen } \\
\text { (building } \\
\text { sites, } \\
\text { workshops, } \\
\text { led } \\
\text { machines) }\end{array}$ & $\begin{array}{l}\text { The whole of this process of evaluation } \\
\text { of competences missed direction for the } \\
\text { workmen. They received an answer } \\
\text { only several months after the course of } \\
\text { the talks. }\end{array}$ & $\begin{array}{l}\text { "But for what is that used all that?" } \\
\text { "It was not the sorrow to do all that, so after one does } \\
\text { not even have an answer so that one asked, I will not } \\
\text { remake it" }\end{array}$ \\
\hline
\end{tabular}


The decisions are regarded as rational, the actors conform to the rules suggested, information is perfect and the cognitive capacities of the actors are infinite. From this point of view, the management tools are made the vehicle, the instrument, by which the performance of the organization will be seen increased. De Vaujany (2005a) opposes to these rationalist models of the reflexive models, which are interested in the capacity of reflexivity of the actors and the dynamic ones of structuring of the organized units combining of the intentional and nonintentional elements. The manager is a reflexive agent which primarily seeks to maintain a balancing in its socio-cognitive designs (rather than to increase its rationality); the organization as the management tools are properties of structural which can entitle or force the action (rather than structural devices which are dedicated to increase rationality); and the structural change is an open psychosociological process and without end (rather than a structural evolution to which one will seek to give finished contents). Thus, the authors militate for the need for paying the attention to the tools and their setting of use. Gilbert (2007: 6) insists on the interest of the study of the management tools of HRM, by considering them on two levels: "On the first level, to recognize them like objects, in their materiality and like such subjected at the same time to functional requirements and - what one sometimes pretends to be unaware of - to the criterion of beautiful, with the mode and commercial consumption. On the second level, to seek under the surface of the tool, the social actor and the individual subject, in the genesis of the tool, its appropriation, its uses like in its effects. It is this combination of the material and social which constitutes the instrumentation of HRM. ". Thus, as we also saw in our empirical study, it is not enough any more to be interested in the adoption of the tools (as decision-making process) but in their appropriation. The concept of appropriation makes the object of studies which take their source in the attempt at comprehension of a "gap" or variation noted between the use laid down of an object, a language, of a tool, and the effective use of this same object, language or tool. The appropriation is the process by which the use envisaged will be rejected, modified or approved by the user. The empirical study led watch two major difficulties making obstacle to the appropriation of this E- HRtool. The first relates to the artefact in itself: the actors considered to be software BNDC not very accessible and not very ergonomic. The second relates to the direction allotted by the actors to the artefact. The appraisers saw there a loss of autonomy in the organization of their work: for this reason the tool could call in question the representation that was made the appraisers of their trade and their role. They also saw there a loss of direction to the glance as of relations which they maintain with their employees, who cannot be replaced simple via this software. The workmen as for them did not charge the managerial interest of this tool which had however pushed with its adoption, and were thus restive with its appropriation. Management, insufficiently implied, did not charge a sufficient interest there to show a real will to use it. With final, the tool did not succeed in forming part of this particular context: so the received answers were too late, reinforcing the 
impression which the tool did not have of concrete impact. But this real problem of appropriation reveals also the limits of the estimated models of the estimated HRM.

\subsection{An prospective approach of the management of competences}

The steps of estimated HRM sometimes showed their limits: a very deterministic and used logic which "contributes to the desocialisation of the Organization" (Boyer, Scouarnec, 2009: 96). Many critics have been formulated for a few years against the first models of estimated HRM: too used practices, centered on the organization, too quantitative (Cadin and $\mathrm{Al}, 2007$ ). The estimated HRM evolved of a design primarily instrumental anticipatrice and to a more qualitative logic and prospectivist marked in particular by the law of social modernization. The futurology does not seek to make forecasts. Indeed, in an increasingly dubious economic context, the strictly estimated models showed their limits. The futurology of the trades proposes to exceed these models known as estimated. Whereas they could have direction at the time as of stable socio-economic periods, they are it much less in period of uncertainty (Boyer, Scouarnec, 2009: 96). The futurology of the trades represents the "early capacity of detection of signals even and especially weak - changes to come, the futurology trade appears in rupture compared to the traditional approaches of estimated management of employment and competences" (Boyer, Wickham, 2002: 147). In this context, the Prométhée group of the "Commissariat Général au Plan" (2004) defines the finalities of the futurology of the trades: to better apprehend the evolutions of the trades in the context of the changes of the job market and the environment (economic, demographic, lawful, cultural, social, technological and organisational), to identify the rooms for maneuver which the companies with the glance have as of changes with work, to light the possible professional paths of the individuals and to anticipate the needs for renewal by work like the formative needs.With the company J, the management tools computerized $N B D C$ propose tools of analysis and assistance to the evaluation contributing to the process of management of competences and more largely to the piloting of HRM. The management of competences evolves but there are still important margins of progression. The observations carried out reveal phenomena of not-appropriation of the tool by the employees, the framing (in particular clerks of works) but also by the management of the firm. In short, our analysis shows that this E-RH tool applied to the GPEC is a system which included people, policies and procedures and data. Beyond the technical functionalities, we also see in this tool a set of human factors and policies essential with its operation. The success of the steps of estimated HRM "depends on its appropriation by the whole of the actors: the employees for which it is intended and the managers, who play a crucial role there to concretize the step and because they are the first appraisers of competences of their collaborators" (Cadin and Al, 2007: 191). Consequently, the futurology of the trades does not fit any more in this deterministic logic and proposes to consider the whole of the possible evolutions of the trades of the company (Boyer, Scouarnec, 2009). 
The approaches more qualitative and are centered on the individual.

\section{References}

AREZKI S., BROSSIER J.C. (2004), « Un cas exemplaire de gestion des compétences dans le BTP », Personnel, n450, p. 40-41, juin.

BARIBEAU C. (2005), « Le journal de bord : un instrument de collecte des données indispensable », Recherches Qualitatives, Vol. HS(2), p. 98-114.

BAUMARD P., DONADA C., IBERT J., XUEREB J.M. (2004), " La collecte des données et la gestion de leurs sources ", p. 224-256, in : THIETART R.A., Méthodes de recherche en management, Paris, Dunod.

BENJAMIN D. (2003), " Les difficultés d'appropriation des NTIC par les acteurs de l'entreprise : quelle contribution possible de la fonction " ressources humaines »", Congrès de l'AGRH, Grenoble, novembre.

BERRY M. (1985), Une technologie invisible : l'impact des instruments de gestion sur l'évolution des systèmes humains, Centre de recherche en gestion de l'école Polytechnique.

BOGDAN R., TAYLOR S.J. (1975), Introduction to qualitative Research methods. A phenomenological Approach to the social Sciences, New York, London John Wiley and Sons.

BOYER L., WICKHAM S. (2002), " La prospective des métiers ", Revue française de gestion, vol. 28, $\mathrm{n}^{\circ} 140, \mathrm{p}$. 147-149.
BOYER L., SCOUARNEC A. (2009), La Prospective des Métiers, Caen, Editions EMS.

BRETON P., PROULX S. (2002), L'explosion de la communication à l'aube du XXIème siècle, Paris, La Découverte ;

CADIN L., GUERIN F., PIGEYRE F. (2007), Gestion des ressources humaines, Paris, Dunod.

CNPF (1998), "Identifier et décrire les compétences professionnelles », Objectifs compétences, Journées de Deauville, tome 4.

Commissariat général du plan, France (2004), Prospective des métiers : Le point de vue des branches, Travaux du groupe Prométhée [en ligne], [réf. du 17 décembre 2008]. Disponible sur <http://www.crefor.asso.fr/crefor2003/ 2/TransparentsJEF07122004/Conference s/CGPlanInterventionC.Afriat.pdf>

COUTELLE P. (2005), Introduction aux méthodes qualitatives en Sciences de Gestion. Cours du CEFAG - séminaire d'études qualitatives 2005 [en ligne], [réf. du 22 mars 2009], Cahier de recherche du CERMAT, vol. 18, $\mathrm{n}^{\circ} 124$, disponible sur : $<$ http://cermat.iae.univtours.fr/IMG/pdf/_05124_PCoutelle.pdf>.

DESCARPENTRIES J.M. (2000), « Pour une approche fractale du Knowledge Management : la théorie des nénuphars », Arthur Andersen Newsletter, $n^{\circ} 4$.

DE VAUJANY F.X. (2005a), « La réflexivité comme alternative à la rationalité : le rendez vous manqué des sciences de gestion ? ", XIVème Conférence 
Internationale de Management Stratégique, Pays de la Loire, Angers.

DE VAUJANY F.X. (2005b). (Sous la direction de), De la conception à l'usage : vers un management de l'appropriation des outils de gestion, Editions EMS.

DIETRICH A., PARLIER M. (2007), « Les accords de gestion prévisionnelle des emplois et des compétences ", Congrès de l'AGRH, Fribourg, septembre.

FAVIER M., KALIKA M., TRAHAND J. (2004), « E-learning/ E-formation : implications pour les organisations ", Systèmes d'information et management, $\mathrm{n}^{\circ} 9$, vol. 4, p. 3-10.

FAYON D. (2009), "Un élément clé du travail collaboratif », Personnel, n499, mai, p. 80-81.

GILBERT P. (1998), L'instrumentation de gestion : la technologie de gestion science humaine ?, Paris, Economica.

GILBERT P., PARLIER M. (2005), « La gestion prévisionnelle des ressources humaines : fondements, bilan et mise en place », p. 489-524, in : WEISS D., Les Ressources Humaines, Paris, Editions d'Organisation.

GRIMAND A. (2006), L'appropriation des outils de gestion : vers de nouvelles perspectives théoriques?, Publications de l'Université de Saint Etienne, Coll. Gestion.

HATCHUEL A., WEIL B. (1992), L'expert et le système, Paris, Economica.

HLADY RISPAL M. (2002), La méthode des cas. Application à la recherche en gestion, Paris, De Boeck Université.
KALIKA M. (2000), " Le management est mort, vive le e-management ! ", Revue française de gestion, $\mathrm{n}^{\circ} 129$, juin-juilletaoût, p. 68-74.

KALIKA M. (2005). (Sous la direction de), e- $\mathrm{RH}$, réalités managériales, Paris, Vuibert.

KALIKA M., LAVAL F. (2006), " Les technologies de l'information et de la communication (TIC) et la fonction ressources humaines (RH) », Cahiers français, $n^{\circ} 333$, p. 1-6.

KALIKA M., LEDRU M., ISAAC H., BEYOU C., JOSSERAND E. (2003), Le emanagement : quelles transformations pour l'entreprise ?, Paris, Editions Liaisons.

LAVAL F., THIERNO DIALLO A. (2007), « L'E-RH : un processus de modernisation de la gestion des ressources humaines à la mairie de Paris ", Revue Management et Avenir, vol. 3, n¹3, p. 124-148.

LORINO P. (2002) «Vers une théorie pragmatique et sémiotique des outils appliquée aux instruments de gestion ", ESSEC, Documents de recherche, juillet.

LORINO P. (2007), "Stylistic creativity in the utiliization of management tools ", Essec Research Center, avril.

MALLET L. (1991), Gestion prévisionnelle de l'emploi, Paris, Editions Liaisons.

MARTIN D. (2006), "Appropriation des outils de gestion et dynamique de l'action collective : propos d'étape ", in : GRIMAND A., L'appropriation des outils de gestion : vers de nouvelles 
perspectives théoriques, Publications de l'Université de Saint-Etienne, p. 29-40.

MOISDON J.C. (1997), Du mode d'existence des outils de gestion, Paris, Editions Seli-Arslan.

RABARDEL P. (1997), "Activités avec instruments et dynamique coginitive du sujet ", in : MORO C., SCHNEUWLY B., BROSSARD M., Outils et signes : perspectives actuelles de la théorie de Vygotski, Peter Lang, p. 35-49.

SZELERSKI J.P. (2009), " Les meilleurs outils couplés aux meilleures expertises humaines font la différence », Personnel, n497, février, p. 66. 